\title{
Amor, desejo e coisas "que me ultrapassam": um estudo interdisciplinar da instituição do matrimônio na Bíblia Hebraica
}

\author{
Suzana Chwarts
}

Universidade de São Paulo

\section{Resumo}

Este artigo apresenta um estudo interdisciplinar da instituição do matrimônio e temas correlatos - como amor, sexualidade, incesto e concepção - na Bíblia Hebraica, a partir de uma seleção de passagens narrativas, proféticas, sapienciais e legais, traduzidas pela autora do texto hebraico massorético. A análise e a tradução dos textos visam à apreensão de seu significado contextual, colocando em relevo os sentidos entrelaçados das palavras hebraicas e sua rede de associações intertextuais. A seleção das passagens evidencia a heterogeneidade das visões de mundo registradas na Bíblia Hebraica, seus modos de expressão literária e as múltiplas vozes dos autores bíblicos.

Palavras-chave: Bíblia Hebraica. Matrimônio. Incesto. Sexualidade. Concepção.

\section{Love, desire, and matters "beyond my comprehension": an interdisciplinary study of marriage in the Hebrew Bible}

\begin{abstract}
This article presents an interdisciplinary study of marriage and related themes - such as love, sexuality, incest, and conception - in the Hebrew Bible, from a selection of narrative, prophetic, wisdom, and legal passages, translated by the author from the Hebrew Masoretic text. The translation and analysis of the texts aim to apprehend their contextual meaning, highlighting the intertwined meanings of the Hebrew words and the network of intertextual associations. The selection of the passages highlights the heterogeneity of worldviews recorded in the Hebrew Bible, their literary modes of expression, and the multiple voices of Biblical authors.
\end{abstract}

Keywords: Hebrew Bible. Marriage. Incest. Sexuality. Conception. 


\section{Amor, deseo y cosas "más allá de mi compreensión": un estudio interdisciplinario del matrimonio en la Biblia Hebrea}

\section{Resumen}

Este artículo presenta un estudio interdisciplinario sobre la institución del matrimonio y temas relacionados - como el amor, la sexualidad, el incesto y la concepción - en la Biblia Hebrea, basado en una selección de pasajes narrativos, proféticos, de sabiduría y legales, traducidos por la autora del texto masorético en hebreo. El análisis y la traducción de textos tienen como objetivo la comprensión de su significado contextual, destacando los sentidos entrelazados de las palabras hebreas y su red de asociaciones intertextuales. La selección de pasajes destaca la heterogeneidad de las cosmovisiones registradas en la Biblia Hebrea, sus modos de expresión literaria y las múltiples voces de los autores bíblicos.

Palabras clave: Biblia Hebrea. Matrimonio. Incesto. Sexualidad. Concepción.

\section{Introdução}

"Há três coisas que são maravilhosas demais para mim, sim, há quatro que não entendo: o caminho da águia no céu, o caminho da cobra na penha,

o caminho do navio no meio do mar e o caminho do homem com uma donzela."

(Pv 30.18-19)

Este estudo focaliza o "caminho do homem com uma donzela", enunciado em Provérbios 30.18-19 como algo que ultrapassa e desafia a compreensão do ser humano comum: as vias insondáveis do amor, do desejo e da concepção. Na Bíblia Hebraica, essas são coisas que devem se manifestar livremente, desde que no âmbito exclusivo da célula conjugal, visando à interação produtiva dos agentes sociais e sua inserção no desenvolvimento estável da comunidade à qual pertencem.

A Bíblia Hebraica, no entanto, não idealiza o matrimônio, e expõe, nos mais diversos textos, as tensões inerentes à circunscrição do desejo e à eclosão de sentimentos ambíguos e dissonantes no seio da família. O Salmo 128, por exemplo, célebre por enaltecer vividamente a harmonia familiar, sintetiza, em suas delicadas metáforas, aspectos didáticos inequívocos que traçam os contornos dessa concórdia em termos espaciais, funcionais e reprodutivos.

Por outro lado, o matrimônio é enfatizado como uma bênção suprema, aspecto salientado pela estrutura do salmo, que apresenta a felicidade conjugal, 
descrita em ordem crescente, envelopada entre duas bênçãos arquetípicas: a bênção inicial do gênero 'ashrêe, "feliz aquele...", que exalta o temor reverencial a Deus, e as bênçãos finais, que vinculam Deus, e aqueles que o temem, a Sião e a Jerusalém, acrescentando mais uma baliza à instituição do matrimônio: sua dimensão sociopolítica.

\section{Harmonia e êxito}

Aprendemos sobre o ideal bíblico da família e da felicidade conjugal, dentre outras passagens, no texto de Salmo128.1-4¹:

O canto das subidas.

Feliz todo aquele que tem temor reverencial a YHWH, caminhante de Seus caminhos.

Do esforço de tuas mãos comerás, serás feliz e te beneficiarás.

Tua mulher, no íntimo de tua casa, como vinha frutífera; teus filhos, como rebentos de oliveira, em volta da tua mesa; eis como será abençoado o homem que tem temor reverencial a YHWH.

YHWH te abençoe de Sião; e vê, o bem de Jerusalém todos os dias de tua vida; e vê, filhos a teus filhos. Paz sobre Israel.

À parte a beleza do salmo, que nos últimos versículos amalgama a felicidade individual do israelita com a prosperidade e perenidade de Israel, são sublinhados, em sua estrutura, alguns dos mais importantes elementos constitutivos do matrimônio e da família bíblica.

Antes de tudo, o casamento ideal descrito no salmo é monogâmico: há uma só esposa e mãe dos filhos, representada metaforicamente como "vinha frutífera", expressão que salienta o dom essencial de uma mulher no contexto conjugal, i.e., sua fertilidade, base para a edificação de uma família, designada em hebraico bíblico como bêt 'av, literalmente, "casa do pai".

\footnotetext{
Todas as traduções da Bíblia Hebraica neste artigo são de nossa autoria, a partir do texto hebraico massorético, exceto o texto em epígrafe, extraído da tradução Almeida Revista e Atualizada (Barueri: Sociedade Bíblica do Brasil, 1993). Fez-se uso da Biblia Hebraica Stuttgartensia (5. ed. Stuttgart: Deutsche Bibelgesellschaft, 1997), editada entre 1967 e 1977. A transliteração dos vocábulos foi simplificada, a fim de propiciar a boa compreensão de sua pronúncia pelos leitores. Esse interesse orienta a forma como estão grafados e acentuados os termos transliterados. Seguindo as convenções da transliteração, os fonemas kh e $c h$ devem ser pronunciados como o caractere $j$ do espanhol ou como o dígrafo $c h$ do alemão.
} 
$\mathrm{Na}$ "casa do pai", o espaço da mãe é definido em termos espaciais e reprodutivos: ela ocupa o recôndito da casa, seu nexo vital. A expressão hebraica beyarketê veiteekha significa, literalmente, "nas coxas de sua casa". Essa locução espacial, que significa o espaço mais interior ou longínquo ${ }^{2}$, remete também ao órgão reprodutor masculino, uma vez que coxa ( $\left.y^{e} r e k h\right)$ é um conhecido eufemismo constante em algumas tradições do Pentateuco ${ }^{3}$. Desse modo, o poder reprodutivo do casal constitui a força propulsora de toda a constelação familiar, que inclui a própria casa, substancializada como um organismo vivo, animado por essa pulsante fertilidade.

A segunda metáfora do salmo, "rebentos de oliveira em volta da tua mesa", alude aos filhos, que brotam em abundância e partilham, com os pais, a fartura da mesa, também essa situada no recesso da casa. A expressão "em volta da tua mesa", além de explicitar circularidade e centralidade, supõe, implicitamente, obediência, uma vez que filhos que comem à mesa de seu pai honram-no ao fazê-lo e estão submetidos à sua autoridade. A expressão, articulada em relação de paralelismo semântico com o termo "coxas", coloca também em relevo a relação de consanguinidade entre pai e filhos, pedra angular da autoridade patriarcal, e a própria fertilidade do pai como genitor.

Videira e oliveira - principais cultivos agrícolas de Israel na Antiguidade - revestem-se de valor simbólico: enquanto a videira denota prazer e descanso $^{4}$, a oliveira expressa perenidade e paz ${ }^{5}$. Os cultivos remetem, ainda, ao fruto dos esforços bem-sucedidos do casal, sendo o êxito a grande promessa do salmo e a consecução da bênção divina àquele que cumpre os preceitos de Deus, ou, na linguagem do salmo, "caminha em Seus caminhos": "... abençoado o fruto do teu ventre, o fruto da tua terra; bendito o teu cesto e a tua amassadeira” (Dt 28.4-5).

Subjaz a essa descrição idílica da vida familiar a ideia de produtividade e usufruto dos abundantes benefícios logrados com esforço. O esforço, a princípio uma consequência da punição do homem e sua mulher no Éden e da maldição da terra (Gn 3.16-19) ${ }^{6}$, é transmutado em bênção, uma vez

2 BROWN, F.; DRIVER, S. R.; BRIGGS, C. A. (Eds.). The Brown-Driver-Briggs Hebrew and English Lexicon. Peabody: Hendrickson, 1996. Disponível em: <biblehub.com>. Acesso em: 5 ago. 2020.

3 Por exemplo, Gênesis 24.2; 46.26; 47.29; Êxodo 1.5.

4 Cf. Gênesis 5.29.

5 A videira e a oliveira carregadas de frutos representam Israel na literatura profética e sapiencial e expressam a relação de amor e cuidado de Deus com Israel, como se vê em Isaías 5.5-7; Oséias10.1-8; Salmo 80, entre outros.

6 Em contraposição à ausência de esforço que imperava na esfera edênica, à mulher serão multiplicados seus esforços ('itstsvonêkhh) e gravidezes, e ao homem caberá o esforço ('itstsavôn) de trabalhar uma terra amaldiçoada com a infertilidade. 
que que gera frutos. O salmo apresenta, portanto, um organograma social harmonioso e pragmático, mas prenhe de significado teológico, no qual cada agente deve atuar em sua própria esfera: o marido, na esfera agrícola; a esposa, na esfera doméstica; ambos, na esfera reprodutiva, fundamentando na ordem social o desígnio divino.

Assim como a paz e a integridade do lar se expandem para incluir a paz e a segurança de Jerusalém e de todo Israel - sendo shalôm um vocábulo polissêmico, que designa simultaneamente paz, integridade e perfeição ${ }^{7}-$, a vida dos pais e dos filhos se estende, cumprindo o percurso que compreende três gerações, mais uma consecução da bênção bíblica:

... observes os estatutos e mandamentos que hoje te ordeno

tu, teu filho e teu neto

todos os dias da tua vida

para que os teus dias se prolonguem. (Dt 6.2)

A ideia de íntima cooperação entre o homem e a mulher fundamenta sua própria criação como entidades separadas e independentes, ou interdependentes. Em Gênesis 2.18, Deus declara: "Não é bom que o humano seja só; farei para ele um auxiliar que lhe corresponda." A expressão bíblica "ézer kènegdô significa, literalmente, "auxiliar que lhe contraponha" (face a face). Note-se que o termo "ézer não é binário ${ }^{8}$.

\section{Complementação: aderir e conhecer}

Um aspecto de complementação será manifesto no plano sexual, na fórmula "o homem adere à sua mulher e são uma só carne". Isso se dá também no plano social, uma vez que "o homem deixa pai e mãe" para, em seguida, aderir à sua mulher. Pode-se depreender dessa elocução que a relação de consanguinidade entre filho, pai e mãe não é condizente com a aderência, no sentido bíblico, e que esse estado é logrado apenas por intermédio da raiz verbal $d v q$, cujo significado literal é "colar". Na passagem de Gênesis 2.24 , isso implica a reunião primordial do humano seccionado em duas partes distintas, embora complementares ${ }^{9}$ : uma afirmação da sexualidade

7 ROWN, F.; DRIVER, S. R.; BRIGGS, C. A. (Eds.). The Brown-Driver-Briggs Hebrew and English Lexicon. Peabody: Hendrickson, 1996. Disponível em: < biblehub.com>. Acesso em: 5 ago. 2020.

8 Idem.

9 O termo tsela', comumente traduzido como "costela", significa também "lado", como se lê em Êxodo 26.26 e Ez 41.26 (BROWN, F.; DRIVER, S. R.; BRIGGS, C. A. (Eds.). The Brown-Driver-Briggs Hebrew and English Lexicon. Peabody: Hendrickson, 1996. Disponível em: < biblehub.com>. Acesso em: 25 jul. 2020). 
como potência de coesão. Nesse contexto, a reprodução não é citada, e a sexualidade é celebrada em sua essência e significado.

Despida de sua conotação sexual, a raiz verbal $d v q$ cumpre a função de designar o alinhamento perfeito do homem justo com Deus, em vários textos bíblicos: "E vós, aderidos a YHWH, vosso Deus, estão todos vivos hoje" (Dt 4.4); "A YHWH, o teu Deus, terás temor reverencial, a ele servirás, a ele aderirás e jurarás em Seu nome" (Dt 10.20) ${ }^{10}$. A fidelidade de Rute à sogra Noemi (Rt 1.14) e dos homens de Judá a Davi (2Sm 20.2), por exemplo, também é nomeada em termos de aderência ${ }^{11}$.

Já na esfera reprodutiva, outro verbo é empregado para estatuir a relação sexual: ladá at - cujo significado literal é "conhecer" -, com o sentido de penetrar a essência do objeto a ser conhecido. Seguindo a lógica semântica, é sempre o homem que penetra a mulher.

No entanto, o campo semântico de ladá'at é tão pleno de significado que os profetas, em suas repreensões sociais, irão aplicar a expressão "conhecimento de YHWH" para apontar justamente aquilo que falta em Israel, e que não pode ser provido apenas pelo rituais no templo, mas, principalmente, por intermédio do aprimoramento moral do indivíduo e a conformação de uma ética capaz de reafirmar o alinhamento com Deus.

O profeta Oseias define esse "conhecimento de YHWH" como um compromisso conjugal irrevogável, fundamentado nos pilares da aliança contratual celebrada entre Deus e Israel no Sinai, a saber: justiça (tsedeq), juízo (mishpat), fidelidade (chesed) ${ }^{12}$, amor uterino (rakhamîm) ${ }^{13}$ e confiança/fé ('emûnah). Ao associar os alicerces da aliança ao verbo da raiz 'rs ${ }^{14}$, o profeta

10 Cf. também Deuteronômio 11.22; 30.20; Josué 22.5 etc.

11 A ideia de acoplamento, na forma substantiva do verbo deveqût, perpassa o pensamento espiritual judaico, sendo formulado no Zohar (Livro do Esplendor) e em outras obras medievais como o estado de enlevação e êxtase alcançado pelo justo, que eleva suas preces e intenções às sefirôt do sistema de emanações divinas (cf. IDEL, M. The privileged divine feminine in Kabbalah. Berlin-Boston: De Gruyter, 2019, p. 35-38).

12 É minha percepção que o termo chesed, amiúde traduzido como "amor" ou "caridade", denota, essencialmente, fidelidade, ou seja, a interdependência que respalda qualquer relação: horizontal, entre humanos, e vertical, entre humanos e Deus.

13 Igualmente traduzo o termo rakhamim como amor uterino, trazendo à tona seu sentido primordial, uma vez que rekhem é útero. Esse seria o amor entranhado, comovido, que desconhece gênero.

14 A raiz 'rs faz referência a uma promessa verbal de casamento, acompanhada de presentes cerimoniais ofertados pela família do noivo à família da noiva, com implicações legais para a noiva, que tem seu status modificado, ainda vivendo na casa de seu pai, como veremos adiante. A lógica da passagem está reforçada no v. 17 de Oseias 2 (no hebraico; na versão Almeida Revista e Atualizada, de 1993, trata-se do v. 15), que ressalta os dias de juventude da moça $\left(y^{e} m e ̂\right.$ n' ùréyha). 
Amor, desejo e coisas "que me ultrapassam": um estudo 265 interdisciplinar da instituição do matrimônio na Bíblia Hebraica

põe em relevo o compromisso conjugal, e não a instituição do matrimônio em si, como lemos em Oseias 2.21-22 $2^{15}$ :

Eu me comprometerei [ $w^{e}$ 'erastikh $h^{\prime}$ contigo - para sempre.

Eu me comprometerei contigo - em justiça e em juízo, e em fidelidade e com amor uterino.

Eu me comprometerei contigo - em confiança; e conhecerás a YHWH.

Assim como o compromisso antecede o conúbio, Oseias retoma a relação de espelho e emparceiramento formulada em Gênesis 2.16 ('îsh, 'ishshah - homem, mulher) para reescrever o discurso matrimonial, borrando seus traços hierárquicos e aludindo à reconciliação iminente de Deus com Israel, alicerçada no princípio de reciprocidade da aliança sinaítica:

Naquele dia, oráculo de YHWH, tu me chamarás: meu homem ['厃̂shî] e não mais me chamarás: meu senhor [ba'all]. (Os 2.18)

Com o sentido literal de "senhor" e a conotação nítida de dominar e governar, o termo ba'al, assim como 'adôn, designa simultaneamente o marido e sua autoridade. Já a esposa é cognominada 'ishshah be'ulat-ba'al (mulher assenhoreada de senhor), como lemos em Gênesis 20.3 em relação a Sara no palácio do rei Abimeleque, em Gerar.

O verbo lada'at inaugura o encadeamento de três verbos que materializam a relação sexual reprodutiva. O primeiro exemplo é a relação entre Adão e Eva, após a expulsão do Éden: "E conheceu Adão à sua mulher, Eva, e concebeu e deu à luz" (Gn 3.1). A fórmula indica, de forma inequívoca, que o objetivo da relação sexual é a concepção, em consonância com a bênção divina primordial "deem frutos, e multipliquem-se, e encham a terra" (Gn 1.28).

Por outro lado, assegura também a relação de consanguinidade com o pai, uma vez que a sequência dos verbos - penetrar/conceber/dar à luz - é feita num só fôlego.

15 Os vs. 21-22 de Oseias 2, no texto original hebraico, correspondem aos vs. 19-20 da versão bíblica Almeida Revista e Atualizada (1993). 


\section{Concepção e suas parcerias}

A fala de Eva, ao dar à luz seu primeiro filho, impõe a presença ativa de um terceiro agente, Deus, e assevera o caráter teológico de toda concepção na Bíblia Hebraica: "Formei um homem com YHWH", ela exclama em Gênesis 4.1.

Ao empregar a raiz verbal $q n h$, com o sentido arcaico de formar ${ }^{16}$, Eva assume uma posição singular como partícipe do processo, sendo ela a única mulher na Bíblia Hebraica a fazer tal afirmação. O nome de seu filho, Caim, reflete essa parceria.

A esse respeito, vale ressaltar que, na tradição bíblica, é corrente a mãe clamar o nome dos filhos a partir de sua própria experiência emocional, um costume com sérias implicações, uma vez que o nome de uma pessoa, na visão de mundo bíblica, denota também a sua essência.

Lia, por exemplo, projeta nos nomes dos filhos tanto a ação benevolente de Deus - que viu que ela era rejeitada por seu marido e abriu o seu útero - como seu desejo de alcançar o amor de Jacó (Gn 29.32-33; 30.20).

Raquel nomina os filhos paridos a Jacó por Bila, sua serva, a partir de sua contenda pessoal com a irmã, e ao dar à luz José, exclama: "Que Deus me acrescente outro!", refletindo, no nome do filho, o seu desejo de ser mãe de muitos. Tal desejo se realiza, mas lhe custa a vida: ela morre dando à luz seu segundo filho. Em seu último alento, ela o nomina ben-'on̂̀ (Benoni), "filho do meu sofrimento", mas Jacó muda o nome da criança para binyamîn (Benjamim), "filho da minha direita" (Gn 35.18).

Outro nome de personagem que designa sua essência e destino é Abel (heve), que significa, literalmente, o que é evanescente e vão ${ }^{17}$. Abel é introduzido obliquamente na narrativa, como um acréscimo, talvez, da relação sexual que gerou Caim, o que lhe vale o epíteto de "seu irmão", antes mesmo de receber um nome - que, aliás, não é clamado nem por sua mãe nem por seu pai, mas informado laconicamente pelo narrador: "e seguiu dando à luz a seu irmão, a Abel” (Gn 4.2). As lacunas no texto são consoantes com a sua finitude e insubsistência.

Os nomes bíblicos masculinos contêm, em sua maior parte, elementos

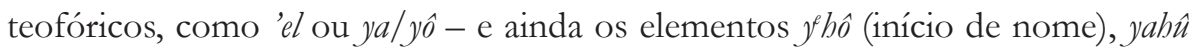

\footnotetext{
16 BROWN, F.; DRIVER, S. R.; BRIGGS, C. A. (Eds.). The Brown-Driver-Briggs Hebrew and English Lexicon. Peabody: Hendrickson, 1996. Disponível em: <biblehub.com>. Acesso em: 3 jul. 2020.

17 Idem.
} 
Amor, desejo e coisas "que me ultrapassam": um estudo 267 interdisciplinar da instituição do matrimônio na Bíblia Hebraica

(final de nome) - e refletem, a meu ver, a relação direta das mulheres com Deus, uma vez que a concepção (assim como a esterilidade) é de natureza divina: Deus abre e fecha o útero das mulheres ${ }^{18}$.

No entanto, uma outra ideia de concepção se impõe na Bíblia Hebraica, em conformidade com a teoria monogenética, vigente em muitas sociedades patriarcais da Antiguidade, segundo a qual o sêmen seria o único elemento constituinte do ser. A palavra hebraica žera' designa, simultaneamente, sêmen, semente e descendência: toda uma visão de mundo condensada em uma palavra $^{19}$. Essa ideia está explicitada na lamentação de Jó, que contém uma rara descrição da formação fisiológica do embrião em etapas sucessivas:

Não me derramaste como leite

e me coalhaste como queijo?

Pele e carne me vestiste,

e com ossos e nervos me teceste.

Vida e fidelidade comigo fizeste

e Seu cumprimento guardou meu sopro.

$[\ldots]$

$\mathrm{E}$ por que do útero me tiraste?

Morreria,

e olho não me teria visto

porque seria como se não tivesse existido

do ventre ao sepulcro levado. (Jó 10.10-12,18-19)

Nessa passagem, pode-se identificar quatro estágios formativos distintos do embrião: (1) o fundamento a partir de um estado fluido e sua associação com o sêmen, por sua cor e consistência; (2) o processo de coagulação, aglomeração e consolidação desse fluido leitoso; (3) a formação de ossos e nervos; e (4) o revestimento de pele e carne.

O útero é tão somente o locus dessa formação, e todo o processo é descrito em termos de uma relação particular entre Jó e Deus, a partir do elemento vital, o sêmen, plasmado e transformado por Deus dentro do útero ${ }^{20}$.

18 Cf., por exemplo, Gênesis 29.31; 30.22; 1Samuel 1.5-6; cf., também, discussão em CHWARTS, S. Uma visão da esterilidade na Bíblia Hebraica. São Paulo: Humanitas, 2004, p. 133-138.

19 BROWN, F.; DRIVER, S. R.; BRIGGS, C. A. (Eds.). The Brown-Driver-Briggs Hebrew and English Lexicon. Peabody: Hendrickson, 1996. Disponível em: <biblehub.com>. Acesso em: 13 jun. 2020.

20 CHWARTS, S. Uma visão da esterilidade na Bíblia Hebraica. São Paulo: Humanitas, 2004, p. 133-138. 
O vocábulo zera', em sua acepção de descendência patrilinear, constitui o fio condutor das promessas e da aliança divina nas narrativas patriarcais, que podem ser compreendidas como uma "fase embrionária" da emergência corporativa de Israel, a partir da história de uma só família, a de Abraão. A essa família, Deus impõe duras provas, e a ação de cada um de seus membros possui importantes desdobramentos teológicos, uma vez que o mérito dessas gerações será a base do favor divino em relação a Israel $^{21}$.

Um dos temas centrais da saga patriarcal é a instituição do matrimônio, que norteia o direcionamento de importantes dinâmicas sociais e econômicas da família e do clã, como veremos adiante.

\section{Matrimônio: sendas entrecruzadas}

É Abraão quem enuncia as leis positivas e negativas sobre o matrimônio, ao enviar o servo Eliézer à casa patriarcal de seu irmão Naor, em Padã-Arã, na Mesopotâmia, para ali buscar uma esposa para seu filho Isaque: “... não tomarás uma mulher para meu filho entre as filhas do cananeu no meio em que habito, mas onde é minha terra, onde foi meu nascimento, irás tomar uma mulher para meu filho" (Gn 24.3-4).

Mas o próprio casamento de Abraão permanece um enigma. Ele toma Sara por esposa em Ur, na Mesopotâmia, mas, uma vez em Canaã e no Egito, ele lhe pede que se passe por sua irmã, para que "eu me beneficie por seu intermédio e que minha vida seja conservada por sua causa” (Gn 12.13).

Sara é incorporada ao harém do Faraó e do rei de Gerar, os quais a devolvem a Abraão, desesperados, uma vez alertados por Deus - por meio de praga e sonho - de que se trata de uma mulher casada. Em sua resposta ao rei de Gerar, Abraão afirma que Sara é, de fato, sua esposa e sua meia-irmã, filha de seu pai, mas não de sua mãe (Gn 12.11-20; 20.2-18).

Seria o casamento entre meios-irmãos possível em Israel? A lei é clara quanto ao interdito, que classifica tal relação como incestuosa: "Maldito aquele que se deita com a sua irmã, filha de seu pai ou filha de sua mãe" (Dt 27.22); "Não descobrirás a nudez da tua irmã, seja ela filha do teu pai ou da tua mãe; quer seja nascida em casa, ou fora dela, não descobrirás sua nudez" (Lv 18.9).

Mas quando Amnom, filho de Davi, violenta sua meia-irmã Tamar, também filha do rei, ela lhe diz:

21 A memória dos patriarcas é consolidada no epíteto divino "Deus de vossos Pais" (Gênesis 50.24-25; Éxodo 3.13-15; Deuteronômio 4.1; 8.1; 9.5; 19.8), que evoca o juramento que Deus fez aos antepassados de Israel (Êxodo 2.24; 32.13-14; Deuteronômio 7.6-8,12; 10.15 ; Isaías 51.1-3). 
Não, meu irmão, não me forces, porque não se faz assim em Israel; não faças essa loucura!

Porque, aonde iria eu com a minha vergonha?!

Agora, pois, peço-te que fales ao rei, porque ele não me negará a ti! (2Sm 13.12-13)

A fala de Tamar indica que, ao menos na família real, a relação entre meios-irmãos seria uma possibilidade; por outro lado, poderia ser apenas uma "saída" retórica improvisada, que, no entanto, não convenceu o violador.

O corpus legal que interdita o incesto inclui também as categorias de irmã do pai e irmã da mãe (Lv 18.12-13). Essas categorias são nominadas, em hebraico bíblico, $s h^{e}$ 'er, cujo significado literal é "carne"22. O termo designa, nas leis do Levítico, as pessoas com relação de consanguinidade entre $\mathrm{si}^{23}$.

Já as expressões "descobrir a nudez" ('kallôt 'erwah) e "ver a nudez" (lirồt 'erwah) constituem um eufemismo para relações sexuais ilícitas (Lv 18.6; 20.17). O termo 'erwah está ligado, no plano etimológico, a 'arah, cujo significado é descobrir, desvelar, desnudar ${ }^{24}$. A nudez, designada como'erwah, constitui uma metáfora para a sexualidade, uma vez que aquilo que é desvelado está bem além da nudez física e diz respeito a essa potência vital do ser, gerida por um rígido código moral, que determina seus contornos, por natureza, desordenados.

Os expedientes do Levítico visam, aparentemente, a um equilíbrio interno da família poligâmica ou policoital, legitimando o poder do patriarca de manter relações sexuais de diversas matizes em sua família estendida, sem, no entanto, multiplicar as relações de consanguinidade em sua família nuclear, que permanece o centro dessa constelação social ${ }^{25}$. A conformação da célula nuclear da família bíblica é apresentada na lei que permite ao sacerdote presenciar o enterro de seis parentes consanguíneos designados como $s h^{\circ}$ er: pai e mãe; filho e filha; irmão e irmã ${ }^{26}$.

\footnotetext{
22 A palavra $s h^{e}$ er denota a porção de comida/carne que o senhor deve dar à escrava em seu poder (Ex 21.10).

23 LEVINE, B. A. The JPS Torah Commentary: Leviticus. Philadelphia: Jewish Publication Society, 1989, p. 119-125.

24 A raiz é cognata do assírio uru, que significa "nudez" e também "deserto"; BROWN, F.; DRIVER, S. R.; BRIGGS, C. A. (Eds.). The Brown-Driver-Briggs Hebrew and English Lexicon. Peabody: Hendrickson, 1996. Disponível em: <biblehub.com>. Acesso em: 11 ago. 2020.

25 GOODY, J. Production and reproduction. Cambridge: Cambridge University Press, 1976, p. 40-48.

26 LEVINE, op. cit., p. 118-125.
} 
Uma exceção, nas leis do incesto, é o casamento levirato. "Levirato", do radical latino levir, que significa "cunhado", é uma instituição na qual o irmão de um homem que faleceu sem deixar filhos deve desposar a viúva dele, a fim de suscitar descendência para o morto, de modo que seu nome não seja apagado em Israel: "E disse Judá a Onã: vai à mulher do teu irmão e cumpra seu papel de cunhado e exerça o levirato com ela [yabbem 'otah] e erga descendência para o teu irmão" (Gn 38.8).

A lei em Deuteronômio 25.5-6 especifica que se dois irmãos moram juntos ${ }^{27}$ e um deles morrer sem filhos, a viúva não se casará fora do clã (nem com um homem de sua preferência), mas seu cunhado deverá tomá-la por esposa e cumprir a obrigação de cunhado. O primogênito dessa relação será o sucessor do falecido, assegurando a sua continuidade e provavelmente herdando seus bens.

A lei, no entanto, prevê que o cunhado pode se recusar a exercer seu direito/dever. Neste caso, ele deverá ser humilhado publicamente, segundo o código de honra e vergonha vigente em Israel: na presença dos anciãos, à porta da cidade, sua cunhada lhe descalçará a sandália do pé e lhe cuspirá no rosto, declarando: "Assim se fará ao homem que não quer edificar a casa do seu irmão." A honra da sua casa patriarcal será para sempre maculada e conhecida em Israel como a "Casa do Descalçado" (Dt 25.7-10).

As narrativas de matrimônio são particularmente reveladoras quanto à autopercepção de Israel como um grupo que enfrenta todo tipo de percalço a fim de asseverar a sua identidade peculiar e assegurar a sua continuidade. Coerentemente, o casamento ideal é monogâmico e endogâmico, entre linhagens aparentadas, de modo a fortalecer os laços de consanguinidade, bem como os acertos econômicos do clã ${ }^{28}$.

As histórias de casamento funcionam também, do ponto de vista literário, como um veículo efetivo para projetar um velado juízo de valor sobre as personagens: enquanto Isaque e Jacó - herdeiros da promessa divina - contraem casamentos endogâmicos com suas primas consanguíneas, Rebeca, Lia e Raquel, os filhos deserdados, Ismael e Esaú, contraem casamentos

\footnotetext{
27 Habitação conjunta, no mesmo bêt 'av, i.e., a família patriarcal estendida (cf. PATAI, R. Sex and family in the Bible and the Middle East. Garden City: Doubleday, 1959, p. 92-93).

28 BLENKINSOPP, J. The family in first temple Israel. In: PERDUE, L. G.; BLENKINSOPP, J.; COLLINS, J. J.; MEYERS, C. Families in Ancient Israel. Louisville: Westminster John Knox Press, 1997, p. 48-51.
} 
exogâmicos, inclusive unindo suas próprias linhagens, excluindo-se duplamente da sucessão patrilinear. Esse feito vem enfatizar a desqualificação de ambos como possíveis herdeiros de Abraão, além de sublinhar sua inadequação como potenciais gestores da linhagem ancestral de Israel.

Ismael habitou no deserto de Parã e sua mãe lhe escolheu uma mulher da terra do Egito. (Gn 21.21)

Quando Esaú completou quarenta anos, ele tomou como mulheres Judite, filha de Beeri, o heteu, e Basemate, filha de Elom, o heteu. E foram amargura de espírito para Isaque e Rebeca. (Gn 26.34)

Esaú viu que seu pai havia abençoado Jacó e o tinha enviado a Padã-Arã para aí tomar para si uma mulher, e o abençoou, ordenando-lhe: "Não tomes uma mulher entre as filhas de Canaã." [...] E viu Esaú que as filhas de Canaã eram más aos olhos de seu pai Isaque; foi à casa de Ismael e tomou como mulher Maalate, filha de Ismael, filho de Abraão e irmã de Nebaiote, além daquelas que possuía. (Gn 28.6-9)

Esse é um exemplo admirável de humor e ironia bíblica. O casamento exogâmico é empregado como paradigma de enganação e armadilha na Bíblia Hebraica, e severamente condenado nos expedientes do Êxodo e do Deuteronômio:

Abstém-se de fazer aliança com os moradores da terra para onde vais; para que não te sejam uma cilada. (Êx 34.12)

Não faças aliança com nenhum deles; nem seus deuses [...] isso lhes será uma cilada. (Ê 23.32)

Não farás aliança com elas [as nações]; não contrairás matrimônio com elas [...] para que não caias numa armadilha. (Dt 7.2,25)

O eixo racional dessa injunção está contido em Deuteronômio 7.3-4:

Não contrairás matrimônio com elas [as nações] não darás tua filha a seu filho, e sua filha não tomarás para seu filho.

Porque [isso] desviará seu filho de mim

E servirão outros deuses, e o furor das narinas de YHWH se inflamaria contra vós, exterminando-te rapidamente. 
No primeiro versículo da passagem em Deuteronômio 7, as nações são designadas como mais numerosas e mais poderosas que os israelitas. Contrair matrimônio exogâmico com grupos majoritários implica ser absorvido e assimilado por tais grupos. A assimilação temida parece ter-se tornado realidade no tempo de Neemias: "Vi também, naqueles dias, que judeus haviam casado com mulheres asdoditas, amonitas e moabitas. Seus filhos falavam meio asdodita e não sabiam falar judaico, mas a língua de seu respectivo povo" (Ne 13.23-24).

O casamento exogâmico encerra uma relação dúplice, uma aliança de connubium et commercium ${ }^{29}$. Um exemplo clássico desse tipo de aliança figura na narrativa de Gênesis 34, que focaliza o clã de Jacó, recém-chegado a Canaã após sua partida da Mesopotâmia, acampando nas imediações da cidade de Siquém. Diná, filha de Lia e Jacó, sai do acampamento para "ver as filhas da terra" e é vista pelo príncipe homônimo da cidade, que a violenta, mas também se apaixona por ela ${ }^{30}$. O príncipe e seu pai buscam negociar o casamento junto a Jacó e seus filhos:

Disse-lhes Hamor: "A alma de meu filho Siquém deseja fortemente a sua filha: peço-lhes que lhe deem [a moça] por esposa. E sejam nossos parentes [wohitchatn $\hat{u}$ 'otan i, deem-nos as suas filhas e tomem as nossas filhas. Habitem conosco; a terra, à sua frente: assentem-se nela e nela negociem e dela tomem posse."

E Siquém falou ao pai e aos irmãos de Diná: “Que eu encontre favor aos seus olhos e o que disserem darei; aumentem de sobremaneira o mohar e as dádivas, e eu darei como disserem, e deem-me a mocinha por esposa." (Gn 34.8-12)

Os irmãos matrilineares de Diná negociam a transação, planejando secretamente resgatar a irmã e vingar a honra do clã, matando todos os homens de Siquém e levando suas mulheres e crianças como escravas. $\mathrm{O}$ saque da cidade condiz, aparentemente, com a noção de compensação financeira pela desonra da filha virgem: “... teria feito como a uma prostituta à nossa irmã?" (Gn 34.31).

O "caso de Diná" se encaixa nos expedientes de Levítico e Deuteronômio, que preveem a violação de uma jovem virgem, a qual poderia ser "mais suavemente" resolvida se Siquém não fosse incircunciso ${ }^{31}$. Segundo

29 FOX, R. Kinship and marriage: an anthropologic perspective. Cambridge: Cambridge University Press, 1996, p. 120.

30 "Sua alma [nefesh] adere a Diná." Sobre a palavra nefesh, cf. WOLF, H. W. Anthropology of the Old Testament. Mifflintown: Sigler Press, 1996, p. 166-177.

31 O matrimônio com um estrangeiro ('îsh zar), presumivelmente circunciso - por viver em Israel e estar atrelado a uma casa patriarcal israelita - era possível até para a filha de um sacerdote, conforme Levítico 22.12. 
a lei, se uma moça virgem não comprometida fosse seduzida e desvirginizada, o homem deveria tomá-la por esposa. Se o pai da moça se recusasse a dá-la, o homem deveria pagar ao pai em dinheiro o mohar hab-betûlôt, i.e., o mohar das virgens (Êx 22.16-17).

Esse tributo está, aqui, claramente dissociado do matrimônio, vinculado diretamente à virgindade da moça que habita na casa de seu pai e à compensação financeira devida ao pai pela perda da virgindade de sua filha, o que provavelmente constituía um dano econômico e social para sua casa patriarcal ${ }^{32}$.

Um texto paralelo estipula que o violador da virgem não comprometida deveria entregar ao pai cinquenta sheqels (siclos) de prata e casar-se com ela:

Se o homem encontrar moça virgem [na'arab betûlab] que não está comprometida [lo'-'orasab33] e a pegar, e se deitar com ela, e forem apanhados, então, o homem que se deitou com ela dará ao pai da moça cinquenta siclos de prata; e, como a maltratou, ela lhe será por mulher; não poderá mandá-la embora durante a sua vida. (Dt 22.28-29)

Note-se a presença da coerção por meio de força física nesta lei, enquanto o expediente em Éxodo 22 ressalta o ato da sedução, e não da violação. No entanto, as duas leis estipulam que o violador deve se casar com a moça seduzida/violentada e pagar ao pai o préstimo costumeiro ${ }^{34}$.

Enquanto a lei em Êxodo 22 outorga ao pai - no livre exercício

32 LEMOS, T. M. Marriage gifts and social change in ancient Palestine: 1200 BCE to 200 CE. Cambridge: Cambridge University Press, 2010, p. 5-38.

33 A raiz verbal 'rs ocorre onze vezes na Bíblia Hebraica (cf. EVEN-SHOSHAN, Abraham [Ed.]. A New Concordance of the Old Testament: Using the Hebrew and Aramaic Text. 2. ed. Grand Rapids: Baker, 1997, p. 119-120). A expressão 'asher lo' 'orasab implica a ausência de compromisso conjugal e o fato de que nenhum mohar (o "preço da noiva") foi pago por essa moça. De acordo com Deuteronômio 20.7, o homem comprometido ('îsh 'asher 'eras) que ainda não se casou está dispensado de ir à guerra. A origem do termo é incerta, e são conhecidos cognatos no ugarítico ('rss) e no acádico (eresu), com o sentido de "requisitar". O radical ' $r$ s corresponde, no hebraico mishnaico ou rabínico, a 'aras, que designa aquele que cultiva a terra; o árabe conserva o significado primordial de "pagar tributo" e "lograr o direito de possessão" (cf. LEMOS, T. M. Marriage gifts and social change in ancient Palestine: 1200 BCE to 200 CE. Cambridge: Cambridge University Press, 2010, p. 5-38).

34 Com referência a esse montante, De Vaux chamou a atenção para duas evidências relevantes: cinquenta sheqels (siclos) corresponde à soma empregada pelo Faraó Amenófis III na compra de uma mulher da cidade de Gezer para seu harém; e a indenização paga ao proprietário pela morte de uma escrava foi fixada em trinta sheqels, em Êxodo 21.32. Já a lei que regulamenta o cumprimento dos votos, em Levítico 27.4-5, estipula o valor de uma mulher adulta em trinta sheqels, e de uma garota menor que vinte anos, em dez sheqels (DE VAUX, R. Ancient Israel: social institutions. V. 1. New York: First McGraw-Hill Book Company, 1965, p. 26-27). 
de sua autoridade patriarcal - plenos poderes para conceder ou não sua filha em casamento, a lei deuteronômica evidencia um sistema judiciário mais complexo, cuja praxis subtrai da autoridade paterna o elemento de arbitrariedade e vincula a violência física à perda do direito de divórcio.

A condição "se forem apanhados" significa "apanhados no ato flagrante por pelo menos duas testemunhas oculares idôneas", e vem proteger o homem de ser acusado injustamente como violador e difamado na sociedade, pela moça ou por sua família ${ }^{35}$.

A lei em Deuteronômio 22.23-27, que delibera sobre a violação de uma moça virgem comprometida com um homem ( $m^{\prime}$ 'orasah l' $\left.{ }^{\prime} \hat{s} h\right)$ ), estabelece que a violação constitui uma ofensa capital, equivalente ao adultério, e não um dano à propriedade, uma vez que a moça em questão é considerada "esposa de outro homem". Se a violação tiver ocorrido na cidade, o violador e a moça serão apedrejados à porta da cidade: a moça, porque não gritou, e o homem, porque violou a mulher do próximo. Se o ato tiver ocorrido no campo, apenas o violador será apedrejado, porque a moça poderia ter gritado, mas não houve quem a escutasse e salvasse.

\section{A noiva-protótipo}

Quem seria, então, a noiva prototípica em Israel? Rebeca. Em sua descrição, no encontro com Eliézer, o servo de Abraão, no poço, são enunciados os requisitos ideais de uma noiva bíblica:

... eis que saiu Rebeca, filha de Betuel, filho de Milca, mulher de Naor, irmão de Abraão, trazendo seu cântaro sobre o ombro.

A moça era muito bela, núbil [betûlah], nenhum homem a conheceu. (Gn 24.15-16)

Aos dados genealógicos objetivos, que indicam que Rebeca é filha de Milca, esposa oficial (e não uma concubina ou serva) de Naor, irmão de Abraão, somam-se beleza, juventude (a palavra betûlah aqui indica que a moça está em idade para se casar) e virgindade. No pano de fundo, estão elencadas as virtudes que denotam nobreza de caráter, na acepção bíblica, demonstradas por Rebeca na recepção do servo: amabilidade, generosidade, hospitalidade.

35 WEINFELD, M. Deuteronomy and the Deuteronomic school. Oxford: Oxford University Press, 1972, p. 120. 
Para coroar as qualidades esponsais de Rebeca e sua caracterização como noiva-protótipo, o amor - que aparece pela primeira vez na Bíblia - selará o seu casamento com Isaque, o primeiro "homo-israeliticus".

Ao se inteirar de tudo que acontecera na Mesopotâmia ${ }^{36}$ e que Rebeca era sua prometida, Isaque "a trouxe à tenda de sua mãe, e a tomou [em casamento] e ela lhe foi por mulher, e a amou, e consolou-se Isaque por sua mãe [ou seja, pela perda de sua mãe]" (Gn 24.66-67).

Betuel e Labão, pai e irmão de Rebeca, são as primeiras personagens bíblicas a associarem a instituição do matrimônio (ao menos o matrimônio com o herdeiro de Abraão) a Deus:

De YHWH saiu a coisa/palavra.

Não podemos dizer a você bom ou mau.

Eis Rebeca à sua frente!

Tome e vá!

E que se torne ela esposa para o filho do teu senhor, como falou YHWH. (Gn 24.50-51)

A palavra-chave nessa elocução é a raiz verbal $d b r$ (falar). O substantivo davar, derivado do verbo ledaber, designa simultaneamente o que é dito e o que é feito, a coisa concreta. A autoridade do pai e do irmão, os quais, efetivamente, dão a noiva em casamento, é aqui emudecida pela natureza divina da transação.

Os parentes de Rebeca empregam o merisma "bom ou mau" para afirmar que nada podem dizer sobre algo dito por Deus. Por outro lado, a elocução "tome[-a] e vá" explicita a dinâmica e a terminologia do matrimônio: casar-se é, em linguagem bíblica, "tomar uma mulher" (laqachat 'ishshah) da casa de seu pai e deslocá-la para a casa de seu marido, onde ela deverá habitar e reproduzir numa relação de exclusividade. $\mathrm{O}$ matrimônio bíblico é, portanto, virilocal ${ }^{37}$.

36 Rebeca havia se encoberto com o véu, ao saber que aquele que caminhava pelo campo, ao longe, em sua direção, era seu noivo Isaque. Esse é um gesto matrimonial, uma vez que na cerimônia de casamento a noiva é apresentada ao noivo coberta com um véu (Gn 24.64-65). Em acádio, a noiva é chamada kalatu kutumtu ("a noiva velada") no dia de seu casamento. Na Mesopotâmia, a cerimônia de elevação de uma concubina aos status de esposa consistia em cobri-la com um véu perante uma corte (cf. PATAI, R. Sex and family in the Bible and the Middle East. Garden City: Doubleday, 1959, p. 62).

37 MEYERS, C. The family in early Israel. In: PERDUE, L. G.; BLENKINSOPP, J.; COLLINS, J. J.; MEYERS, C. Families in Ancient Israel. Louisville: Westminster John Knox Press, 1997, p. 13-26. 


\section{Ruptura e futilidade}

Como a esposa vive na casa de seu marido, o divórcio, na Bíblia Hebraica, uma prerrogativa do homem, consiste em mandá-la embora de casa, dando em sua mão um "escrito de repúdio" (Dt 24.1; Is 50.1; Jr 3.8), o qual the permitirá desposar outro homem. Esse documento é designado como sêfer keritut, que significa, literalmente, "escrito de corte", inscrevendo o divórcio no âmbito da aliança contratual.

Essa relação de pertinência é semanticamente acentuada pelo fato de que, na linguagem bíblica, selar uma aliança é literalmente "cortar uma aliança" (likerôt berît), como na expressão inglesa cut a deal.

Se o homem tomar uma mulher e a desposar e acontecer de esta não encontrar graça a seus olhos, por ter nela encontrado a nudez de algo ['erwat davar ${ }^{38}$ ] e ele escreve para ela um "escrito de corte" [sêfer kêrîtut] e lhe dá em sua mão e a manda embora de sua casa, saiu de sua casa e foi e casa-se com outro homem, esse último não se agrada dela [ûs $\left.{ }^{e} n e^{\prime} a b\right]$ e escreve para ela um "escrito de corte" e lhe dá em sua mão e a manda embora de sua casa ou esse último, que a tomou por mulher, morre; não pode o seu primeiro marido, que a mandou embora, voltar a tomá-la por mulher para ele, após ela ter-se maculado [ huttamma'ah] porque é uma coisa ilícita [tô'evah] perante YHWH e não farás pecar a terra que YHWH, teu Deus, te dá como possessão. (Dt 24.1-4)

Não se sabe ao certo o que é designado pela expressão 'erwat davar, mas é certo que o termo 'erwah indica algo impróprio, ilícito, com indiscutível conotação sexual, que pode ser ausência de sinais de virgindade ${ }^{39}$ ou outra coisa qualquer. O fato é que o homem não necessita de justificativa para se divorciar, como está claro no caso do segundo marido: se ele não se agradar

38 Literalmente, "nudez da coisa/algo" (BROWN, F.; DRIVER, S. R.; BRIGGS, C. A. [Eds.]. The Brown-Driver-Briggs Hebrew and English Lexicon. Peabody: Hendrickson, 1996. Disponível em: <biblehub.com>. Acesso em: 5 ago. 2020).

39 Já a lei em Deuteronômio 22.13-22 protege a mulher de ser difamada pelo marido, que a acusa de não ser virgem: se um homem toma uma mulher, vai a ela e não se agrada dela [s'ne'ab], e lhe atribui coisas devassas/sem fundamento e a difama, impondo-lhe um mau nome, dizendo: "Essa mulher desposei e me aproximei [sexualmente] dela e não encontrei nela [sinais] de virgindade [ b́tullîm]", se o pai e a mãe da moça comprovarem a virgindade da filha - mediante apresentação do lençol com sinais de sangramento ao conselho de anciãos, às portas da cidade -, o marido será açoitado, pagará ao pai da moça cem siclos de prata (o dobro do mohar costumeiro) e não poderá se divorciar dela. Caso contrário, a moça será apedrejada, uma vez que cometeu adultério, profanando o compromisso conjugal, além de desonrar a casa de seu pai. 
da mulher e rejeitá-la, ele pode simplesmente mandá-la embora.

Lia, a esposa imposta a Jacó na falácia perpetrada por Labão, pai da moça, encaixa-se nessa categoria de esposa:

\section{E viu YHWH}

Que Lia não era amada [s'nû'ah]

E abriu o seu útero.

E Raquel, estéril. (Gn 29.31)

Embora não haja registro de um preconceito explícito contra a mulher repudiada, a ideia de mácula é patente em Deuteronômio 24.3-4, e reforçada em Levítico 21.7,14, proibindo ao sacerdote casar-se com as seguintes categorias de mulher:

prostituta, profanada [não virgem], repudiada e viúva.

$[\ldots]$ mas virgem de seu povo tomará por mulher;

e não profanará a sua descendência entre o seu povo, porque

Eu Sou YHWH, que o santifico. (Lv 21.7,14-15)

Em Levítico 22.13, o costume de uma esposa repudiada ou viúva sem descendência retornar à casa de seu pai está preservado:

E a filha do sacerdote que for viúva ['almanah] ou divorciada $\left[g^{g} r \hat{u} s h a b^{40}\right]$ vem e volta à casa de seu pai, como em sua juventude, do pão de seu pai comerá.

\section{A casa da mãe}

Como já visto, bêt 'av, ou "casa do pai", designa a família estendida na Bíblia Hebraica. Em poucas, mas significativas instâncias, figura também a expressão bêt 'em, "casa da mãe" ${ }^{41}$, cujo significado exato é incerto. Essa expressão parece aludir ao núcleo espacial materno na constelação familiar: um quarto na casa ou tenda onde a mãe habitava com os filhos pequenos durante a infância. A expressão nos daria a conhecer, portanto, a rara e subjetiva perspectiva dos filhos.

\footnotetext{
40 Literalmente, "expulse".

${ }^{41}$ LOCH, D. I. Marriage and family in ancient Israel. In: CAMPBELL, K. M. (Ed.). Marriage and family in the biblical world. Down Grove: InterVarsity Press, 2003, p. 39-45.
} 
Na narrativa de seu encontro com Eliézer, servo de Abraão, no poço, Rebeca corre para contar aos da "casa de sua mãe" (bêt 'immah) todas as coisas que se passaram ( $\mathrm{Gn}$ 24.28).

No Cântico dos Cânticos, a amante deseja aninhar o "amado de sua alma" na casa de sua mãe (bêt 'em) e proteger o amor dos elementos, dos homens, dos perigos. No poema, a simbologia uterina é inequívoca, e a casa de mãe é configurada como um domínio mítico, protetor e fecundo, que, no entanto, não invalida a dimensão de um espaço real que evoca intimidade e comunhão.

Quem dera fosses como irmão para mim, amamentado nos seios de minha mãe.

Te encontraria fora, te beijaria e não me desprezariam.

Te conduziria e te traria à casa de minha mãe [bêt 'immî] [ela] me ensinaria;

[te] daria de beber do vinho aromático, do néctar das minhas romãs.

Sua mão esquerda, embaixo de minha cabeça e sua direita me abraça. (Ct 8.1-3)

Nessa parte do poema, perfaz-se uma fusão fantasiosa, motivada pelo desejo de que o amante seja amamentado pelos seios da mãe, o amor celebrado em seus domínios subterrâneos. A relação com a mãe e com o recinto que lhe é próprio é realçada pelo fato de a amada ser única para sua mãe, sua filha favorita (Ct 6.9). Também Isaque é nomeado nesses mesmos termos: “... seu filho, seu único, a quem amas, Isaque” (Gn 22.2). A tenda de Sara, para onde ele leva sua noiva, é, sem dúvida, um bêt 'em, um espaço visceral, onde Isaque encontra o amor de sua esposa e o consolo por sua mãe.

Cabe ter em mente a associação entre consolo e amamentação na imagética de Isaías: " para que mamem e se saciem dos seios de sua consolação" (Is 6.11)O consolo divino é representado por uma cena própria de um bêt 'em: "e mamareis, serão carregados no colo e acalentados nos joelhos. Como alguém a quem sua mãe consola, assim eu os consolarei...”( Is 66.12-13).

\section{Sexualidade e regozijo}

Mesmo em uma literatura mais insípida, como a do Livro de Provérbios, o amor conjugal exalta a sexualidade: 
Bebe água da tua cisterna

$\mathrm{E}$ os fluidos de dentro de teu poço

Transbordariam tuas fontes para fora,

pelas praças teus ribeiros?

Que sejam somente teus, para ti

E não para estrangeiros [que habitam] contigo

Que tua fonte seja abençoada

e contente-se da esposa de tua juventude

corça de amores e gazela encantadora

que seus seios te saturem em todos os tempos

e, em seu amor, desencaminhe-se, sempre. (Pv 5.15-19)

Poço e cisternas, símbolos essencialmente femininos e uterinos, e rios e ribeiros, símbolos masculinos, ressaltam a ideia bíblica de vitalidade e fertilidade, que tem na imagética da água corrente seu signo mais representativo.

O elemento fluido - que caracteriza o sêmen, o leite dos seios, o útero e o prazer sexual - é predominante na bênção primordial, proferida pelo patriarca Jacó a José, fruto do seu amor por Raquel:

bênçãos dos céus no alto,

bênçãos do abismo

acocorado embaixo,

bênção de seios e útero. (Gn 49.25)

A natureza do prazer sexual feminino é explicitada na fala de Sara, quando ela se ri intimamente do anúncio de que terá um filho em sua idade avançada: “Após ter murchado, terei prazer[?] e meu senhor é velho" (Gn 18.12).

O termo hebraico empregado por Sara para expressar prazer é 'ednah, da mesma raiz de 'eden, o jardim de prazeres plantado por Deus, continuamente regado por um rio que se dividia em quatro braços, incluindo o Tigre e o Eufrates (Gn 2.10) ${ }^{42}$. Assim como o Éden é um jardim regado, para Sara, 'ednah designa volúpia, prazer úmido, sexual. Que refrescante é ouvir, da matriarca estéril e anciã, o riso e uma expressão tão livre do paraíso feminino!

42 A palavra acadiana 'edinu, que tem origem no sumério, significa "planície", "estepe". O topônimo acadiano bit 'adini designa a região dos dois lados do Eufrates. Em hebraico, o termo, associado ao radical 'adan, significa desfrutar, ter prazer (HARRIS, R. L.; ARCHER JR., G. L.; WALTKE, B. K. [Orgs.]. Dicionário internacional de teologia do Antigo Testamento. São Paulo: Vida Nova, 1998, p. 1079). 


\section{Assim disse YHWH:}

Ainda se ouvirá neste lugar que vocês dizem desolado, sem homem e sem animal Nas cidades de Judá e nas ruas ermas de Jerusalém sem homem, sem habitante, sem animal a voz do gozo e a voz da alegria a voz do noivo e a voz da noiva. (Jr 33.10-11)

Esse amor marital, em sua fragilidade, é também protegido pela lei: "O homem comprometido não se juntará ao exército, nem lhe será imposto qualquer encargo que o afaste de casa; ele deverá passar um ano, livre, em sua casa, para alegrar a mulher que tomou por esposa" (Dt 24.5). Segundo a tradição interpretativa da Bíblia, os direitos maritais da esposa também seriam protegidos e garantidos:

Se [o pai] tomar para o filho outra [mulher]

Seu alimento, sua vestimenta e sua resposta ['onatab] não diminuirá [à primeira]. (吕x 21.10)

O termo 'onatah é compreendido como direitos conjugais da mulher na Septuaginta, na Peshitta, nos Targuns e na literatura rabínica, sem possuir, no entanto, suporte filológico que fundamente essa interpretação ${ }^{43}$. Em outra passagem legal, em Deuteronômio 13.7, a esposa é chamada "mulher do teu regaço", uma forma poética de designar a intimidade e o amor conjugal ${ }^{44}$.

Na Bíblia Hebraica, o contato físico e emotivo, como abraçar e beijar em público, era comum entre parentes:

E Jacó beijou Raquel, ergueu sua voz e chorou. [...]

E quando Labão ouviu sobre Jacó, filho de sua irmã, correu-lhe ao encontro e o abraçou e o beijou. (Gn 29.11,13)

43 SARNA, N. M. The JPS Torah Commentary: Exodus. Philadelphia: Jewish Publication Society, 1989, p. 134.

44 Essa lei adverte contra a idolatria e elenca as pessoas queridas do círculo íntimo de um homem: "teu irmão, filho de tua mãe, ou teu filho ou tua filha ou a mulher do teu regaço ['eshet chêqékha] ou teu companheiro, que é como a tua alma" (Dt 13.7). 
Em Gênesis 26.8-9, a intimidade entre Rebeca e Isaque, que aparentemente a acaricia ou brinca com ela $\left(m^{e} t s a c h e q\right)^{45} \mathrm{em}$ público, desperta, no rei de Gerar, a desconfiança de que são marido e mulher, e não irmãos, como Isaque havia afirmado.

Outra cena de inequívoca intimidade, no caso, pré-conjugal, retrata Rute deitada aos pés de Boaz, na eira, à noite.

Chegou de mansinho e lhe descobriu os pés e se deitou; e ocorreu que, à meia-noite, assustou-se o homem e se soergueu e eis que uma mulher está deitada a seus pés. E disse: Quem és tu? E disse: Eu sou Rute, tua serva; estende tuas asas sobre a tua serva, porque tu és resgatador. (Rt 3.7-9)

Aqui, Boaz toma o cuidado de preservar a reputação de Rute - que permaneceu deitada aos seus pés até a manhã - levantando-se muito cedo, antes que alguém os pudesse reconhecer, dizendo: "Que não se saiba que a mulher veio à eira" (Rt 3.14).

A lei preserva a dignidade da mulher estrangeira cativa, parte do despojo de uma batalha: se um homem for à guerra, e vir, entre os cativos, uma mulher de belo porte e a desejar, não poderá simplesmente apossar-se dela, mas deverá levá-la para dentro de sua casa. Lá, ela raspará a cabeça, cortará as unhas e despirá o "vestido do cativeiro" - um rito de passagem - e lamentará seu pai e sua mãe por um mês. Só então o homem irá a ela, a desposará e ela lhe será por mulher. E se não a desejar mais, deverá mandá-la embora, segundo a vontade dela ${ }^{46}$, o que significa que não poderá vendêla por dinheiro nem se impor a ela como senhor, porque a "afligiu com violência" (Dt 21.10-14).

\section{Rivalidade e desconsolo}

A estreita ligação entre lei e narrativa, no contexto matrimonial, também está evidenciada na categorização das esposas como 'abûvah (amada) e $s^{e} n \hat{u}$ 'ah (não amada, rejeitada). Essas categorias corresponderiam, na narrativa, a Raquel e Lia, nas histórias que compõem o tumultuado relacionamento conjugal de Jacó com as duas irmãs.

\footnotetext{
45 BROWN, F.; DRIVER, S. R.; BRIGGS, C. A. (Eds.). The Brown-Driver-Briggs Hebrew and English Lexicon. Peabody: Hendrickson, 1996. Disponível em: <biblehub.com>. Acesso em: 23 jul. 2020.

46 "Segundo a vontade dela" parece implicar que ela pode permanecer na casa como escrava ou retornar à casa de seus pais como mulher livre.
} 
Se alguém possuir duas mulheres - uma amada e a outra rejeitada - e ambas lhe tiverem dado filhos, se o primogênito for da mulher rejeitada, este homem, ao repartir a herança entre seus filhos, não poderá tratar o filho da amada como se fosse o primogênito, em detrimento do filho da rejeitada. (Dt 21.15-16)

Outro enredo sobre a rivalidade entre esposas inaugura o ciclo narrativo do Livro de Samuel: Elcana, um homem da tribo de Efraim, possuía duas esposas: Ana e Penina. Embora as esposas sejam apresentadas nessa ordem de importância, Penina tinha filhos e Ana, não os tinha, porque Deus havia fechado o seu útero, como nos informa o narrador onisciente (1Sm 1.5). Mas Ana era amada, e seu marido lhe dava uma dupla porção de comida, quando sacrificavam a Deus no santuário de Siló. Penina, "sua rival" (tsaratah), provocava Ana - perturbando-a e fazendo-a sentir-se miserável. E como isso se repetia ano após ano, Ana chorava e não comia. Então seu esposo lhe perguntava: "Ana, por que choras? Por que não comes? Por que estás desanimada? Não sou eu melhor para ti do que dez filhos?" (1Sm 1.8). O significado primordial de tsarah, "rival" (1Sm 1.6), é "estreito", palavra que designa problema, angústia e opressão ${ }^{47}$.

No âmbito legal, o expediente que regulamenta relações incestuosas inclui a irmã da esposa e explicita a rivalidade entre elas, empregando o verbo litsror: "Não tomarás a irmã da esposa por mulher para rivalizar [litsror] descobrindo sua nudez [l'gallôt 'erwatah] enquanto [a primeira esposa] é viva" (Lv 18.18).

\section{Valor e benfício}

Em Rute 3.1, Noemi formula a ideia utópica do matrimônio como repouso $\left(\operatorname{manô}^{a} c h\right)^{48}$. Tendo em vista os esforços de Rute nos campos de Boaz, essa noção, peculiar a Noemi, é compreensível.

Rute é chamada "mulher valorosa" ('eshet chaîl) por Boaz, que, por sua vez, é nomeado, pelo narrador, como homem valente e valoroso (gibôr chaîl $)^{49}$. O casal está, portanto, alinhado por essa qualidade moral, que se reflete em suas ações.

47 BROWN, F.; DRIVER, S. R.; BRIGGS, C. A. (Eds.). The Brown-Driver-Briggs Hebrew and English Lexicon. Peabody: Hendrickson, 1996. Disponível em: < biblehub.com>. Acesso em: 9 ago. 2020.

48 O termo é empregado em Gênesis 8.9 em relação à pomba que Noé, cujo nome hebraico também implica repouso, solta: "E não encontrou a pomba repouso [manô ch] para seus pés." A pomba então volta à arca, e vai e volta mais uma vez, até ir para não mais retornar (Gn 8.9-12).

49 Expressões como gibôr chayil, 'îsh châul, 'anshê châil e b’nê cháâl designam vigorosos homens de valor (Js 1.14; 6.2; 8.3; 10.7; Jz 6.12; 11.1; 18.2; 20.46; 21.10; $1 \mathrm{Sm} \mathrm{2.4;} \mathrm{10.26;} 14.48$ etc.). 
O vocábulo chaîl não é binário, e designa força, eficiência e valor. ${ }^{50} \mathrm{Na}$ Bíblia Hebraica, o termo figura, principalmente, no contexto das guerras de Israel, exaltando a valentia e a habilidade dos homens de guerra, tanto os de Israel como os seus inimigos ${ }^{51}$. Pertinente, essencialmente, à esfera masculina, chaîl faz referência a mulheres apenas nos livros de Rute e Provérbios.

Em Provérbios 12.4, a mulher valorosa é apresentada como um adereço de seu marido, que lhe confere honra e majestade: "A mulher valorosa é o diadema de seu marido" ('eshet chaîl 'ateret ba'alah). Provérbios 31 expande essa máxima, dando visibilidade à mulher em si. A introdução contém as palavras do rei Lemuel, ensinadas por sua mãe. Nos versículos de abertura, chaîl afirma o vigor sexual masculino, que não deve ser desperdiçado:

O que [te direi] meu filho,

filho de meu ventre,

filho dos meus votos?

Não dês às mulheres teu vigor [chêlekhba]

e teus caminhos às que arruínam reis. $(\operatorname{Pv}$ 31.1-3)

O vigor viril de Lemuel, designado como chaîl, deve encontrar como recipiente uma mulher de valor equivalente, difícil de ser encontrada, segundo sua mãe (v. 4):

Mulher valorosa ['eshet chaîl]

quem [a] achará?

Seu preço [mikrah]

ultrapassa o de pérolas... (Pv 31.10)

50 STRONG, J. Strong's exhaustive concordance of the Bible. Nashville: Abingdon Press, 1980. Disponível em: <biblehub.com>. Acesso em: 26 jul. 2020).

51 O guerreiro israelita é chamado gibôr chaîl e também îsh milchamah ("homem de guerra") em 1Samuel 16.18 e em Jeremias 48.14. Assim também são designados os mil homens valentes hábeis na espada (2Sm 24.9), Jeroboão, homem valente (1Rs 11.28), o capitão das forças de Israel (1Rs 15.20), o homem valente que era leproso (2Rs 5.1), Simeão, comandante da tsavah, o exército de Israel (1Cr 12.26), Joabe, comandante do exército de Davi (sar chayil; 2Sm 24.2,4), os arqueiros (1Cr 8.40), o exército dos caldeus (2Rs 25.5,10), o exército do rei da Babilônia (Jr 34.1,7; 35.11; 37.10) e o exército do Faraó (Êxx 14.9; Dt 11.4; Jr 37.7). Em 2Samuel 22.40, o vocábulo chayil designa a força para a batalha, e em Números 24.18; 31.14 , a coragem de Israel e dos oficiais de seu exército. A expressão define, ainda, os homens capazes (Gn 47.6) e os homens valorosos tementes a Deus (Ê 18.21,25). Fora do contexto bélico, cháil indica riqueza (Is 8.4; 10.14; Sl 62.10; 73.12; 149.6,10), valor (Dt 3.18; 8.17 etc.) e o poder de Deus (S1 59.11; 110.3). Já em Salmo 118.15, expressa a ação divina ('osseh chayil) (STRONG, J. Strong's exhaustive concordance of the Bible. Nashville: Abingdon Press, 1980. Disponível em: < biblehub.com>. Acesso em: 26 jul. 2020). 
Segue-se uma descrição detalhada de uma mulher dinâmica, excepcionalmente laboriosa e exitosa em todas as suas empresas: "Como navio mercante, que traz a comida de longe" (v. 14), "não come o pão do ócio" (v. 27), "sua lâmpada não se apaga à noite" (v. 18), "estende a mão ao fuso, mãos que pegam na roca" (v. 19), "considera um campo e toma-o, com o fruto de suas mãos planta uma vinha" (v. 16), "compra a lã e o linho e os trabalha com habilidade" (v. 13), "tece lençóis e os vende, e faixas dá ao cananeu" (ou ao mercador; v. 25). "Vestida de força ['oz] e esplendor, sorri para o futuro", seus filhos erguem-se em sua presença e a bendizem, e seu marido a louva (vs. 25,28).

Suas virtudes morais também são enaltecidas: ela estende a mão ao pobre, ajuda o desprovido, é temente a Deus (v. 30) e suas obras caridosas são louvadas nos portões da cidade (v. 31).

$\mathrm{O}$ aspecto guerreiro, intrínseco ao termo chaîl, está explicitado no v. 17: "cinge os quadris com sua força e empodera os seu braços" (chag rah be'ôz. motnéyha wat' ammets źro 'ôteyha). Note-se a repetição da palavra 'ôz, que denota força e poder.

A expressão "cingir os quadris" pertence à esfera da ação, da decisão e do combate ${ }^{52}$. A imagética por trás da expressão está possivelmente relacionada a uma atitude que diz respeito ao vestuário do homem bíblico, que consistia em uma longa túnica e um manto (samlah). Ao cingir os quadris com um cinturão ou faixa (chagôrah), a túnica era erguida à altura dos joelhos, transformando-se em saiote, indumentária dos guerreiros israelitas. Cingir os quadris, assim, equivaleria, em linguagem figurativa, a torna-se um guerreiro, pronto para a ação.

Coerentemente, o verbo lachgôr designa combatentes: cem homens cingidos com suas armas de guerra (chagûr ke lê milchamah; hechagûr kelê hammilchamah; Jz 18.11,17); homens cingidos de cinturão, aptos a portar couraça (mik-kol choger chagorab; 2Rs 3.21 ${ }^{53}$.

Seria possível pensar que essa fraseologia, indicativa de coragem e disposição para a batalha, obscurece a feminilidade da esposa, masculinizando-a. No entanto, é preciso ter em mente que a esposa bíblica não estava dissociada

\footnotetext{
52 Eliseu ordena a Geazi: “Cinja os quadris!” (chagor motneykha), ou seja, "prepare-se para agir!” (2Rs 4.29), com o mesmo sentido em 2Reis 9.1; Levítico 8.7; Éxodo 12.11 etc.

53 O verbo lachgôr é empregado, no feminino, para enfatizar o luto de Israel: "Lamenta como a virgem, cingida de saco pelo marido de sua juventude" (kiv'tûlah chagûrat-saq 'al-bá'al $n^{e}$ ‘uréyha) (Jl 1.8; cf. também Jr 49.3).
} 
da guerra: Débora, juíza e profetisa em Israel, comandou o exército das tribos contra o rei de Hazor, e Jael cravou uma estaca da tenda no crânio de Sísera, comandante do exército do rei canaanita (Jz 4.4-22.).

Coragem e determinação são as marcas distintivas da mulher bíblica: Sara, Rebeca, Raquel, Miriã, Zípora, Ester, as parteiras hebreias, e outras que, desprovidas de autoridade, exerceram o poder a seu alcance, "cingiram os quadris" e fizeram avançar, a passos largos, a história de Israel, segundo o plano de Deus.

\section{Conclusão}

Neste ensaio, procurou-se demonstrar que a Bíblia Hebraica é uma literatura provocativa, que suscita mais perguntas do que respostas, principalmente quando aborda questões profundas e ambíguas, essencialmente humanas.

As questões pertinentes ao matrimônio, pilar da sociedade patriarcal, jamais são tratadas de forma esquematizada e árida, mas por meio de considerações nuançadas e prenhes de significado, colocando em relevo o labirinto das emoções das personagens na narrativa e na poética, e dos agentes sociais, nos expedientes legais e na literatura sapiencial.

Desejo e sexualidade são as forças motrizes que nutrem o relacionamento do casal na célula conjugal, bem como o imperativo da reprodução. A relação sexual é enaltecida pelo emprego de uma terminologia dotada de profundo valor teológico, que celebra a reunião primordial entre o homem e a mulher, assim como sua sexualidade, como força de coesão.

$\mathrm{Na}$ poética, poços e cisternas, símbolos essencialmente femininos e uterinos, e rios e ribeiros, símbolos masculinos, ressaltam a ideia bíblica de vitalidade e fertilidade. E, na narrativa, a anciã Sara fala de prazer sexual úmido (Gn 18.12). Seios e útero, por sua vez, são evocados na bênção primordial de Gênesis 49.25, e os direitos maritais da esposa, garantidos pela lei em Levítico 21.10 e Deuteronômio 24.5.

Já em Deuteronômio 13.7, a esposa é chamada "mulher do teu regaço “, uma forma poética de designar a intimidade e o amor conjugal, demonstrados em público por Isaque e Rebeca.

Outro ponto destacado é que a lei bíblica impõe limites ao desejo masculino, preservando a dignidade da mulher cativa - que deverá ser desposada - e protegendo a esposa de ser difamada por seu marido após 
a noite de núpcias. O desejo desenfreado, por outro lado, leva à violência, como é explicitado nos relatos de Tamar (2Sm 13) e Diná (Gn 34).

A rivalidade entre esposas é evidenciada tanto na narrativa - Raquel e Lia, Ana e Penina - quanto na lei (Dt 21.15; Lv 18.18), e o mesmo é observado com relação ao casamento endogâmico, exogâmico e levirato.

Por fim, Rebeca, a noiva-protótipo de Gênesis 24 - aparentada, bela, virgem - não corresponde à esposa-protótipo de Provérbios 31, levando-se em conta a sua atuação em Gênesis 27. E cabe a Elcana, um personagem menor, o papel de marido ideal, e não a Abraão ou a Jacó.

Enfim, "o caminho do homem com uma donzela" (Pv 30.19) revela-se tortuoso e desafiador, e por isso mesmo é abordado, na Bíblia Hebraica, em toda a sua pungente beleza e fragilidade.

\title{
Glossário de categorias sociais pertinentes à instituição do matrimônio:
}

\author{
'ishshah - mulher, esposa \\ 'îs - homem, marido \\ báal - senhor, marido \\ 'adôn - senhor, marido \\ kalah - noiva, nora \\ chatan - noivo, genro \\ $m^{e}$ 'orashah - comprometida \\ 'îsh 'asher 'eras - comprometido \\ yabam - cunhado \\ y vamah - cunhada \\ chamôtah - (sua) sogra \\ $g^{e} v \hat{i r a h}$ - senhora \\ 'amah - escrava, serva \\ pilegesh - concubina \\ tsarah - (esposa) rival \\ 'ahûvah - (esposa) amada \\ $s^{e} n \hat{u}$ 'ah - (esposa) rejeitada, não amada \\ $g^{e}$ rûshah - repudiada \\ $b^{e} t \hat{u l a h}$ - jovem, virgem \\ 'aqarah - estéril (f.)
}




$$
\begin{aligned}
& \text { 'em - mãe } \\
& \text { 'av - pai } \\
& \text { ben - filho } \\
& \text { bat - filha, nora } \\
& \text { bekhôr - primogênito } \\
& \text { 'ach - irmão } \\
& \text { 'achôt - irmã } \\
& \text { 'almanah - viúva } \\
& \text { yatôm - órfão } \\
& \text { zera' - descendência consanguínea }
\end{aligned}
$$

\section{Referências}

Biblia Hebraica Stuttgartensia. 5. ed. Stuttgart: Deutsche Bibelgesellschaft, 1997.

BÍBLIA SAGRADA. Almeida Revista e Atualizada. Barueri: Sociedade Bíblica do Brasil, 1993.

BLENKINSOPP, J. The family in first temple Israel. In: PERDUE, L. G.; BLENKINSOPP, J.; COLLINS, J. J.; MEYERS, C. Families in Ancient Israel. Louisville: Westminster John Knox Press, 1997, p. 48-51.

BLOCH, D. I. Marriage and family in Ancient Israel. In: CAMPBELL, K. M. (Ed.). Marriage and family in the biblical world. Down Grove: InterVarsity Press, 2003, p. 39-45.

BROWN, F.; DRIVER, S. R.; BRIGGS, C. A. (Eds.). The Brown-Driver-Briggs Hebrew and English Lexicon. Peabody: Hendrickson, 1996. Disponível em: <biblehub.com>. Acesso em: 8 ago. 2020.

CHWARTS, S. Uma visão da esterilidade na Bíblia Hebraica. São Paulo: Humanitas, 2004. DE VAUX, R. Ancient Israel: social institutions. V. 1. New York: First McGraw-Hill Book Company, 1965.

EVEN-SHOSHAN, Abraham (Ed.). A New Concordance of the Old Testament: using the Hebrew and Aramaic text. Grand Rapids: Baker, 1997.

FOX, R. Kinship and marriage: an anthropologic perspective. Cambridge: Cambridge University Press, 1996.

GOODY, J. Production and reproduction. Cambridge: Cambridge University Press, 1976.

HARRIS, R. L.; ARCHER JR., G. L.; WALTKE, B. K. (Orgs.). Dicionário internacional de teologia do Antigo Testamento. São Paulo: Vida Nova, 1998.

HERCZEG, Y. I. (Ed.). Exodus. The Torah with Rashi's Commentary translated, annotated, and elucidated. Artscroll Series. New York: Mesorah Publications, 1998.

IDEL, M. The privileged divine feminine in Kabbalah. Berlin-Boston: De Gruyter, 2019. 
LEMOS, T. M. Marriage gifts and social change in ancient Palestine: 1200 BCE to 200 CE. Cambridge: Cambridge University Press, 2010.

LEVINE, B. A. The JPS Torah Commentary: Leviticus. Philadelphia: Jewish Publication Society, 1989.

MEYERS, C. The family in early Israel. In: PERDUE, L. G.; BLENKINSOPP, J.; COLLINS, J. J.; MEYERS, C. Families in Ancient Israel. Louisville: Westminster John Knox Press, 1997, p. 13-26.

PATAI, R. Sex and family in the Bible and the Middle East. Garden City: Doubleday, 1959.

SARNA, N. M. The JPS Torah commentary: Exodus. Philadelphia: Jewish Publication Society, 1989.

STRONG, J. Strong's exhaustive concordance of the Bible. Nashville: Abingdon Press, 1980. Disponível em: < biblehub.com>. Acesso em: 9 ago. 2020.

TETLOW, E. M. Women, crime, and punishment in ancient law and society. The Ancient Near East. V. 1. New York: Continuum, 2004.

WEINFELD, M. Deuteronomy and the Deuteronomic school. Oxford: Oxford University Press, 1972.

Submetido em: 24-9-2020

Aceito em: 27-11-2020

Arqueóloga bíblica e professora livre-docente de Estudos Interdisciplinares da Bíblia Hebraica na Faculdade de Filosofia, Letras e Ciências Humanas da Universidade de São Paulo. E-mail: schwarts@usp.br. <http://lattes.cnpq.br/7651954721116854>. 